\title{
PROCES INTEGRACJI EUROPEJSKIEGO RYNKU USŁUG PŁATNICZYCH - WYZWANIA REGULACYJNE
}

\begin{abstract}
WSTĘP
Europejski rynek płatności jest w ostatnich latach przedmiotem głębokich, daleko idących transformacji. Wynika to $\mathrm{z}$ faktu, że postępujący proces integracji gospodarczej i będącej jej elementem integracji monetarnej umożliwia, a z drugiej strony wymusza, wprowadzanie nowych instrumentów czy rozwiązań prawnych zwiększających efektywność procesów gospodarczych m.in. przez urzeczywistnienie swobody przepływu kapitału i płatności między państwami. Niebagatelnym czynnikiem rozwoju rynku płatniczego jest także dostęp do najnowszych technologii, a więc ogromny potencjał techniczny i technologiczny, jaki pozostaje obecnie do dyspozycji uczestników rynku. W tym kontekście zrozumiałe jest zwiększenie intensywności działań dla stworzenia jednolitego rynku płatniczego, co jest celem zmian legislacyjnych aktualnie podejmowanych zarówno na szczeblu unijnym, jak i krajowym. Idea ta realizowana jest przez ustanowienie wspólnych ram prawnych dla unijnego rynku usług płatniczych oraz utworzenie Jednolitego Europejskiego Obszaru Płatniczego SEPA (ang. Single Euro Payment Area). Prace podejmowane dla urzeczywistnienia tych zamierzeń, wzajemnie komplementarne, mają w konsekwencji pozwolić na osiągnięcie zintegrowanych i wydajnych rynków płatniczych.

Dokonując $z$ tej perspektywy analizy kierunków oraz obszarów realizowanych, a także projektowanych działań prawodawczych wskazać należy przede wszystkim, że dla stworzenia nowoczesnych i zharmonizowanych ram prawnych dla usług płatniczych mających zastąpić zróżnicowane krajowe przepisy zapewniające we wszystkich państwach członkowskich koordynację wymogów ostrożnościowych, dostęp nowych dostawców usług płatniczych do rynku, jednakowe wymogi informacyjne, a także odpowiednie prawa i obowiązki użytkowników usług płatniczych i dostawców usług płatniczych przyjęto tzw. dyrektywę
\end{abstract}


$\mathrm{PSD}^{1}$. W dalszej kolejności konieczne stało się także zagwarantowanie spójności prawnej między dyrektywą PSD a rozporządzeniem regulującym płatności transgranicznie ${ }^{2}$, a ponadto zmodyfikowanie zasad, którym podlegają instytucje pieniądza elektronicznego, tak aby zapewnić równe warunki konkurencji dla wszystkich dostawców usług płatniczych ${ }^{3}$.

Realizacja koncepcji jednolitego rynku płatności wymaga nie tylko zniesienia barier prawnych, ale również technicznych - utrudniających dokonywanie płatności między obywatelami, instytucjami i organami publicznymi czy przedsiębiorcami w całej Europie. W państwach UE istnieją bowiem także różnice co do stosowanych instrumentów płatniczych ${ }^{4}$. W celu wyeliminowania tych negatywnych czynników sektor bankowy podjął działania w zakresie samoregulacji branży. W 2002 r. powołana została Europejska Rada ds. Płatności (European Payments Council - EPC), której celem jest wspieranie i promowanie utworzenia SEPA. Jednolity Europejski Obszar Płatniczy ma być obszarem, w którym konsumenci, przedsiębiorstwa oraz inne podmioty będą mogli dokonywać zarówno krajowych, jak i transgranicznych płatności w euro oraz takie płatności otrzymywać, na podstawie tych samych zasad, praw i obowiązków, bez względu na miejsce dokonywania operacji ${ }^{5}$. Tym samym celem SEPA jest zacieśnienie integracji europejskiej dzięki stworzeniu konkurencyjnego i innowacyjnego rynku płatności detalicznych w euro, który pozwoli na zwiększenie efektywności produktów płatniczych, a także stosowanie tańszych sposobów dokonywania płatności.

Prowadząc rozważania nad zakresem potrzebnych zmian legislacyjnych, wskazać należy na konieczność dokonania rozstrzygnięć w dwóch aspektach. $Z$ jednej strony odpowiedzieć trzeba na pytanie, w jakim stopniu niezbędna jest regulacja

1 Dyrektywa Parlamentu Europejskiego i Rady 2007/64/WE z dnia 13 listopada 2007 r.w sprawie usług płatniczych w ramach rynku wewnętrznegozmieniająca dyrektywy 97/7/WE, 2002/65/WE, 2005/60/WE i 2006/48/WE i uchylająca dyrektywę 97/5/WE, Dz.U. UE L 319 z 5.12.2007, s. 001-036 .

W związku z czym przyjęte zostało nowe rozporządzenie w sprawie płatności transgranicznych (Rozporządzenie Parlamentu Europejskiego i Rady (WE) nr 924/2009 z 16 września 2009 r. w sprawie płatności transgranicznych we Wspólnocie oraz uchylające rozporządzenie (WE) nr 2560/2001, Dz.U. UE L 266 z 9.10.2009 r., s. 011-018), przywoływane dalej jako: rozporządzenie nr 924/2009 w sprawie płatności transgranicznych we Wspólnocie.

Uchwalona została nowa dyrektywa w sprawie podejmowania i prowadzenia działalności przez instytucje pieniądza elektronicznego oraz nadzoru ostrożnościowego nad ich działalnością (Dyrektywa Parlamentu Europejskiego i Rady 2009/110/WE z dnia 16 września 2009 r. w sprawie podejmowania i prowadzenia działalności przez instytucje pieniądza elektronicznego oraz nadzoru działalnością, zmieniająca dyrektywy 2005/60/WE i 2006/48/WE oraz uchylająca dyrektywę 2000/46/WE, Dz.U.UE.L 267 10.10.2009, s. 007-017, przywoływana dalej jako dyrektywa EMD II.

4 SEPA Migration end-date. Discussion Paper, PSMEG/002/10, 15.03.2010, http://www.europeanpaymentscouncil.eu, s. 4.

Single Euro Payments Area. Sixth Progress report, www.ecb.int. 
na poziomie europejskim, a jaka możliwa na poziomie krajowym, by osiągnąć cel jakim jest zintegrowany, jednolity rynek usług płatniczych, a dalej, jakie zmiany prawne winny zostać wprowadzone przez organy stanowiące prawo na każdym z poziomów. $Z$ drugiej zaś, jak nowe możliwości technologiczne pozwalające na oferowanie nowych usług i produktów płatniczych wpłyną na kierunki działania prawodawców: unijnego i krajowych. To one w znacznej mierze wyznaczać będą obszar wyzwań legislacyjnych.

\section{PROBLEMY PRAWNE INTEGRACJ EUROPEJSKIEGO RYNKU USŁUG PŁATNICZYCH NA POZIOMIE UNIJNYM}

Stworzenie jednolitego rynku w 1992 r. oraz wprowadzenie euro w 1999 r. rozpoczęło proces integracji rynków finansowych WE, a także zwiększyło intensywność działań normodawczych. Osiągnięcie celu, jakim jest jednolity rynek płatniczy, wymaga bowiem zwiększonej aktywności prawodawcy unijnego, tak by zniwelować różnice i usunąć bariery, jakie tworzą krajowe systemy płatnicze dla płatności transgranicznych, a także zwiększyć efektywność i konkurencję na rynku ${ }^{6}$. Działalność prawodawcza organów unii podlega jednak ograniczeniom. Przede wszystkim o możliwości stanowienia prawa unijnego w określonych dziedzinach decydują przyznane w traktatach ${ }^{7}$ kompetencje (wyłączne bądź dzielone między UE a państwa członkowskie). Dodatkowo istotne dla wyznaczenia zakresu możliwej ingerencji są traktatowo usankcjonowane zasady: pomocniczości (subsydiarności) i proporcjonalności. Granice kompetencji UE wyznacza zatem zasada przyznania, przy czym stanowienie prawa pochodnego może zachodzić wówczas i tylko w takim zakresie, w jakim cele podejmowanych działań nie mogą być osiągnięte w sposób wystarczający przez państwa członkowskie i jeśli ze względu na rozmiary lub skutki proponowanego działania możliwe jest lepsze ich osiągnięcie na poziomie wspólnoty. Ponadto zakres i forma działania UE nie mogą wykraczać poza to, co jest konieczne do osiągnięcia celów traktatów ${ }^{8}$. Zasadniczym wyzwaniem stojącym przed organami stanowienia prawa, a także Komisją Europejską jako instytucją inicjatywy ustawodawczej jest zatem ocena, kiedy i w jakim zakresie konieczna jest interwencja prawodawcy unijnego. W obszarze rynku finansowego działania legislacyjne skupiają się dotychczas

\footnotetext{
6 Por. J. A. Usher, The Law of Money and Financial Services in the EC, Oxford 2000, s. 150; K. Lannoo, EU Retail Financial Market Integration: Mirage or Reality?, European Credit Research Institute Policy Brief No. 3/2008, s. 1-2.

7 Traktat o Unii Europejskiej (dalej: TUE) i Traktat o funkcjonowaniu Unii Europejskiej, wersje skonsolidowane DzU UE C 83 z 30.3.2010 r., s. 001-388, przywoływane dalej jako: Traktaty.

8 Art. 5 TUE.
} 
przede wszystkim na zapewnieniu konkurencji, stosownego poziomu ochrony konsumentom, bezpieczeństwa rynku, a także likwidacji granic wewnętrznych w UE w celu umożliwienia swobodnego przepływu usług, kapitału i płatności ${ }^{9}$. Wydane zalecenia, dyrektywy i rozporządzenia harmonizowały bądź ujednolicały przepisy dotyczące: zasad funkcjonowania i świadczenia usług na rynku płatni$\operatorname{czym}^{10}$, bezpośrednio transakcji transgranicznych ${ }^{11}$, a także zapobiegania praniu pieniędzy ${ }^{12}$. Zasadnicze znaczenie dla prawodawcy wspólnotowego ma zapewnienie konsumentom możliwości korzystania $\mathrm{z}$ wysokiej jakości usług finansowych, w tym płatniczych. Wyznaczając zakres planowanych prac legislacyjnych, KE podkreśla przede wszystkim konieczność niwelowania fragmentacji rynków płatniczych oraz zapewnienia efektywności europejskiego rynku płatniczego, dostępu do ogólnoeuropejskich produktów płatniczych, m.in. przez wspieranie działań na rzecz rozwoju SEPA ${ }^{13}$. W obszarze rozważanych kierunków inicjatyw

9 Por.m.in.Biata Ksiega. Polityka w dziedzinie ustug finansowych na lata 2005-2010 \{SEC(2005) 1574\}, Komisja Wspólnot Europejskich, Bruksela, dnia 1.12.2005 COM (2005) 629 final, http:// ec.europa.eu

10 Zalecenie Komisji 87/598/EEC z 8 grudnia 1987 r. w sprawie europejskiego kodeksu właściwego zachowania w zakresie elektronicznych instrumentów płatniczych (dotyczące relacji między instytucjami finansowymi, akceptantami i agentami rozliczeniowymi i konsumentami); Dz.U. UE L 365 z 24.12.1987, s. 072-076; Zalecenie 88/590 Komisji z 17 listopada 1988 r. dotyczące systemów płatności, w szczególności stosunków pomiędzy posiadaczem karty i wydawcą karty, Dz.U. UE L 317 z 24.11.1988, s. 055-058; Zalecenie Komisji 90/109/EWG z dnia 14 lutego 1990 r. w sprawie przejrzystości warunków bankowych związanych z zagranicznymi transakcjami finansowymi, Dz.U. UE L 67 z 15.03.1990, s. 039-043; Zalecenie Komisji nr 97/489/EC z 30 lipca 1997 r. w sprawie transakcji dokonywanych przy użyciu elektronicznych instrumentów płatniczych, w szczególności stosunków pomiędzy wydawcą a posiadaczem, Dz.U. UE L 208 z 02.08.1997, s. 052-058; Dyrektywa 2006/48/WE Parlamentu Europejskiego i Rady z dnia 14 czerwca 2006 r. w sprawie podejmowania i prowadzenia działalności przez instytucje kredytowe, Dz.U. UE L 177 z 30.06.2006, s. 001-003; Dyrektywa 2000/46/WE Parlamentu Europejskiego i Rady z dnia 18 września 2000 r. w sprawie podejmowania i prowadzenia działalności przez instytucje pieniądza elektronicznego oraz nadzoru ostrożnościowego nad ich działalnością, Dz.U. UE L 275 z 27.10.2000, s. 039-043 (przywoływana dalej jako dyrektywa EMD); Dyrektywa EMD II.

11 Dyrektywa 95/5/WE Parlamentu Europejskiego i Rady z 27 stycznia 1997 r. w sprawie transgranicznych przelewów bankowych; Dz.U. UE L 043 z 14.02.1997, s. 025-030; rozporządzenie (WE) nr 2560/2001 Parlamentu Europejskiego i Rady z dnia 19 grudnia 2001 r. w sprawie płatności transgranicznych w euro, Dz.U. UE L 344 z 28.12.2001, s. 013-016 (przywoływane dalej jako: rozporządzenie nr 2560/2001 w sprawie płatności transgranicznych w euro); Rozporządzenie nr 924/2009 w sprawie płatności transgranicznych we Wspólnocie.

12 Rozporządzenie (WE) nr 1781/2006 Parlamentu Europejskiego i Rady z dnia 15 listopada 2006 r. w sprawie informacji o zleceniodawcach, które towarzyszą przekazom pieniężnym, Dz.U. UE L 345 z 8.12.2006 r., s. 001-009.

13 Zob. m.in. Commission staff working document - Initiatives in the area of Retail Financial Services - Accompanying document to the Communication from the Commission to the European Parliament, the Council, the European Economic and Social Committee and the Committee of the Regions - A single market for 21st century Europe $\{\mathrm{COM}(2007) 724$ final\} $\{\mathrm{SEC}(2007) 1517\}$ \{SEC(2007) 1518\} \{SEC(2007) 1519\} \{SEC(2007) 1521\}, http://eur-lex.europa.eu 
i propozycji regulacji prawnych są także te dotyczące technologii informacyjno-komunikacyjnych (ICT), niezbędnych m.in. dla prawidłowego funkcjonowania „e-rynku wewnętrznego", ze względu na istniejące ryzyko przyjęcia przez państwa członkowskie niekompatybilnych rozwiązań technologicznych, co negatywnie wpływałoby także na rynek usług płatniczych ${ }^{14}$.

Obecnie dla stworzenia warunków dla integracji i racjonalizacji krajowych systemów płatniczych, a także produktów płatniczych w państwach należących do Europejskiego Obszaru Gospodarczego (dalej: EOG), najistotniejsze znaczenie ma uchwalona przez Parlament Europejski i Radę dyrektywa PSD ustanawiająca wspólne ramy prawne dla europejskiego rynku płatniczego Wspólnoty. Przyjęcie tej dyrektywy zainicjowało szereg dalszych zmian normatywnych na szczeblu unijnym, a także w prawie krajów EOG.

\section{JEDNOLITY RYNEK USŁUG PŁATNICZYCH - RAMY PRAWNE}

Zgodnie z założeniami przyjętymi w dyrektywie PSD dla osiągnięcia jednolitego rynku usług płatniczych państwa EOG muszą dokonać harmonizacji krajowych przepisów prawnych w zakresie prawa publicznego i prywatnego. Analizując przepisy tej dyrektywy w odniesieniu do pierwszego obszaru, przede wszystkim podnieść należy, że ustanowiła ona nowe zasady dostępu usługodawców do rynku usług płatniczych mające pozwolić na wzmocnienie konkurencji między krajowymi rynkami płatności (otwarcie rynków dla stosownych dostawców oraz zapewnienie im równorzędnych warunków świadczenia usług płatniczych).

Mocą jej postanowień podmiotami wyłącznie uprawnionymi do świadczenia usług płatniczych są tzw. dostawcy usług płatniczych (enumeratywnie wymienieni w dyrektywie PSD). Kraje implementujące omawianą dyrektywę zobowiązane zostały do wyróżnienia sześciu następujących kategorii tych dostawców: instytucje kredytowe (w tym znajdujące się we Wspólnocie oddziały instytucji kredytowych posiadających główną siedzibę we Wspólnocie lub poza Wspólnotą) ${ }^{15}$, instytucje pieniądza elektronicznego, instytucje świadczące żyro pocztowe uprawnione do świadczenia usług płatniczych zgodnie z prawem krajowym, instytucje

14 Zob. m.in. Komunikat Komisji dla Parlamentu Europejskiego, Rady, Europejskiego Komitetu Ekonomiczno-Społecznego i Komitetu Regionów - Jednolity rynek Europy XXI wieku $\{$ KOM(2007) 725 wersja ostateczna\} $\{\operatorname{SEK}(2007) 1517\}\{\operatorname{SEK}(2007) 1518\}$ SSEK(2007) 1519\} $\{\mathrm{SEK}(2007) 1520\}\{\mathrm{SEK}(2007) 1521\} / \mathrm{COM} / 2007 / 0724$ końcowy, Bruksela, dnia 20.11.2007 r., http://eur-lex.europa.eu

15 W rozumieniu dyrektywy 2006/48/WE Parlamentu Europejskiego i Rady z 14 czerwca 2006 r. w sprawie podejmowania i prowadzenia działalności przez instytucje kredytowe (wersja przeredagowana). Chodzi o art. 4 ust. 1 lit. a, art. 4 ust. 3 oraz art. 38 tej dyrektywy. 
płatnicze, Europejski Bank Centralny i krajowe banki centralne, gdy nie działają one w charakterze organów publicznych oraz państwa członkowskie UE lub ich władze regionalne lub lokalne, gdy nie działają one w charakterze organów publicznych ${ }^{16}$. Istotnym elementem przyjętych rozwiązań prawnych było wprowadzenie obok dotychczas istniejących kategorii instytucji finansowych takich jak instytucje kredytowe czy instytucje pieniądza elektronicznego, nowej - instytucji płatniczych. Instytucje płatnicze to podmioty świadczące usługi płatnicze na podstawie licencji wydanej przez państwo macierzyste i poddane nadzorowi zgodnie z zasadami prawa krajowego. Ich działalność jest zatem reglamentowana i nadzorowana przez poszczególne państwa EOG, z uwzględnieniem zasad: jednolitego paszportu oraz nadzoru państwa macierzystego ${ }^{17}$. Jednocześnie dyrektywa PSD określa normatywne wymogi, których spełnienie jest konieczne dla uzyskania zezwolenia na podjęcie i prowadzenie działalności przez instytucje płatnicze (kapitałowe, personalne, reguły ostrożnościowe etc.), ujednolicając reżim licencyjny.

$\mathrm{Na}$ poziomie regulacji unijnych został wyznaczony zakres przedmiotowy działalności instytucji płatniczej. Może ona prowadzić działalność gospodarczą w zakresie obejmującym świadczenie usług płatniczych ${ }^{18}$ (dominujący przedmiot działalności) oraz innych usług dozwolonych dyrektywą PSD, co w zamierzeniu prawodawcy powinno pozwolić na wyraźne odróżnienie instytucji płatniczej od innych instytucji.

Na krajowym rynku finansowym obok instytucji płatniczych usługi świadczyć mogą także podmioty traktowane jako instytucje płatnicze. Ich działalność jest działalnością rejestrowaną i podlega ograniczeniom terytorialnym (nie są uprawnione do świadczenia usług poza państwem macierzystym) i co do wielkości całkowitej kwoty transakcji. Precyzując najistotniejsze warunki podejmowania i prowadzenia działalności przez podmioty traktowane jako instytucje płatnicze, prawodawca unijny pozostawił każdemu z państw EOG swobodę decydowania o dopuszczeniu ich do funkcjonowania na krajowym rynku usług płatniczych

16 Dla celów dyrektywy PSD dostawca usług płatniczych oznacza nie tylko podmioty wymienione w jej art. 1 ust. 1, ale także osoby prawne i fizyczne korzystające z wyłączenia na mocy art. 26 tej dyrektywy (art. 4 pkt 9 dPSD).

17 Niemniej jednak także organy Europejskiego Systemu Nadzoru Finansowego, w tym przypadku Europejski Urząd Nadzoru Bankowego, mają stosowne kompetencje do podejmowania m.in. działań koniecznych dla zapewnienia skutecznego i spójnego stosowania unijnych przepisów prawnych, zob. Rozporządzenie Parlamentu Europejskiego i Rady Nr 1093/2010 z dnia 24 listopada 2010 r. w sprawie ustanowienia Europejskiego Urzędu Nadzoru (Europejskiego Urzędu Nadzoru Bankowego), zmiany decyzji nr 716/2009/WE oraz uchylenia decyzji Komisji 2009/78/WE, Dz.U. UE L 331 z 15.12.2010 r., s. 012-047.

18 Usługi płatnicze, których dotyczy dyrektywa PSD, zostały zdefiniowane w załączniku do tej dyrektywy. 
oraz o wyłączeniu stosowania całości lub części procedury i warunków przyjętych dla instytucji płatniczych.

W ramach swojej działalności zarówno instytucje płatnicze, jak i podmioty traktowane jako instytucje płatnicze mogą korzystać z usług agentów, oddziałów lub podmiotów świadczących usługi w ramach outsourcingu, ponosząc pełną odpowiedzialność za wszelkie działania tych podmiotów ${ }^{19}$.

Odrębną grupę regulacji stanowią te dotyczące prawa prywatnego. W dyrektywie przyjęte zostały rozwiązania w zakresie ochrony konsumentów, zawierające postanowienia dotyczące praw i obowiązków związanych $\mathrm{z}$ dostarczaniem i korzystaniem $z$ usług płatniczych ${ }^{20}$, a także zabezpieczeń przed utratą środków $z$ tytułu nieautoryzowanych transakcji ${ }^{21}$. Pozwala to na zharmonizowanie relacji prawnych między dostawcami usług płatniczych a ich użytkownikami, co niewątpliwie przyczyni się do realizacji projektu na rzecz jednolitego obszaru płatności w euro ${ }^{22}$. Niemniej jednak postanowienia dyrektywy PSD odnoszą się do usług świadczonych w państwach UE zarówno w euro, jak i w walucie państwa członkowskiego poza strefą euro ${ }^{23}$.

Obok dyrektywy PSD istotnym aktem prawnym regulującym obecnie zasady świadczenia usług płatniczych jest dyrektywa EMD II. Jej przyjęcie wynika, po pierwsze, $z$ potrzeby zapewnienia zgodności regulacji dotyczących emisji pieniądza elektronicznego oraz podejmowania i prowadzenia działalności przez instytucje pieniądza elektronicznego (dalej: ELMIS) z dyrektywą PSD, po drugie, $z$ konieczności usunięcia barier utrudniających rozwój rynku tego pieniąazza ${ }^{24}$.

19 Szerzej: J. Byrski, Outsourcing w dziatalności dostawców ustug ptatniczych na tle dyrektywy w sprawie ustug ptatniczych w ramach rynku wewnętrznego, „Przegląd Prawa Handlowego” 2009, nr 9, s. 44 i n.

20 M.in. obowiązkowy, standardowy czas wykonania zlecenia, odpowiedzialność wykonawcy zlecenia za jego prawidłową realizację oraz gwarancja pełnej i terminowej płatności, a także uproszczone i w pełni zharmonizowane zasady dotyczące wymogów informacyjnych mające zapewnić m.in. większą przejrzystość rynku.

21 Zob. B. Bacia, A. Zawidzka, Swoboda przeptywu kapitatu i ustugi finansowe w Unii Europejskiej, Warszawa 2011, s. 86-90; J. Gliniecka, Zasada przejrzystości swiadczenia ustug ptatniczych jako warunek bezpiecznego korzystania z elektronicznych instrumentów ptatniczych na tle rozwiazan prawnych dyrektywy PSD, „Prawo Bankowe” 2008, nr 6, s. 45 i n.; D. Mavromati, The Law of Payment Services in the EU. The EC Directive on Payments Services in the Internal Market, Kluwer Law International, The Netherlands 2008, s. 189-228.

22 Zgodnie z założeniem jej twórców dyrektywa PSD wyznacza ramy prawne pozwalające na utworzenie jednolitego obszaru płatności w euro, por. np. Wspólne oświadczenie Europejskiego Banku Centralnego i Komisji Europejskiej dotyczace przyjęcia przez Parlament Europejski dyrektywy w sprawie ustug ptatniczych, Reference: IP/07/550, dzień: 24/04/2007, http://europa.eu

${ }_{23}$ Por. M. van Empel, Retail payments and the arduous road to SEPA, „Common Market Law Review” 2009, vol. 46, No. 3, s. 921 i n.

${ }^{24}$ Obowiązujące dotychczas zasady działalności instytucji pieniądza elektronicznego określone w dyrektywie EMD okazały się zbyt restrykcyjne. Były one tworzone z myślą o tradycyjnym modelu świadczenia usług finansowych i wzorowane na rozwiązaniach przyjętych dla instytucji kre- 
W celu umożliwienia powstania rzeczywistego, jednolitego rynku usług w zakresie pieniądza elektronicznego w Unii Europejskiej dokonano zmian dotychczasowych rozwiązań w kilku obszarach: złagodzono wymogi ostrożnościowe (m.in. obniżenie wysokości kapitału zakładowego) oraz rozszerzono zakres prowadzonej przez ELMIS działalności, przyjęto także nowe definicje „pieniądza elektronicznego" $i$,instytucji pieniądza elektronicznego”. Jak podkreślała KE, ma to pozwolić na opracowanie nowych, innowacyjnych i bezpiecznych usług $\mathrm{z}$ wykorzystaniem pieniądza elektronicznego, zapewnienie dostępu do rynku nowym uczestnikom oraz sprzyjanie rzeczywistej i skutecznej konkurencji między wszystkimi uczestnikami rynku ${ }^{25}$.

Stworzenie podstaw prawnych dla zintegrowanego rynku usług płatniczych wymagało także zmiany przepisów dotyczących przelewów transgranicznych. Dotychczas obowiązujące rozporządzenie nr 2560/2001 w sprawie płatności transgranicznych w euro miało istotny wpływ na europejski sektor systemów płatności, który został zachęcony do stworzenia obejmującej całą UE infrastruktury płatniczej stanowiącej warunek powstania jednolitego obszaru płatności w euro. Niemniej jednak przyjęcie dyrektywy PSD, a także zmiany zachodzące na rynku spowodowały, że niezbędne stało się wprowadzenie nowych rozwiązań prawnych. Na mocy uchwalonego we wrześniu 2009 r. rozporządzenia nr 924/2009 w sprawie płatności transgranicznych we Wspólnocie m.in. rozszerzona została zasada „równych opłat”, zmienione wymogi sprawozdawcze do celów statystycznych, a także nałożony obowiązek wyznaczenia pozasądowych organów rozjemczych właściwych $\mathrm{w}$ sporach związanych $\mathrm{z}$ rozporządzeniem o współpracy między organami poszczególnych państw w przypadku rozstrzygania sporów transgranicznych ${ }^{26}$.

Analizując przyjęte regulacje, trzeba mieć na względzie, że stworzone ramy prawne dla świadczenia usług płatniczych nie są jednak ani zupełne, ani nie wpro-

dytowych. Nadmierne, nieproporcjonalne obciążenia zniechęcały do prowadzenia tej działalności i ograniczały wprowadzanie innowacyjnych rozwiązań technologicznych. Jak wskazano we wniosku Komisji Europejskiej (wniosek KE z dnia 9.10.2008 r. Dyrektywa Parlamentu Europejskiego w sprawie podejmowania i prowadzenia działalności przez instytucje pieniądza elektronicznego oraz nadzoru ostrożnościowego nad ich działalnością, zmieniająca dyrektywy 2005/60/WE i 2006/48/ /WE oraz uchylająca dyrektywę 2000/46/WE (Tekst mający znaczenie dla EOG) \{SEK(2008) $2572\}\{\operatorname{SEK}(2008) 2573\} / K O M / 2008 / 0627$ wersja ostateczna - COD 2008/0190; http://eur-lex. europa.eu) „z danych liczbowych dotyczących ograniczonej liczby instytucji pieniądza elektronicznego posiadających pełne zezwolenie lub niewielkiej ilości emitowanego pieniądza elektronicznego wynika, że funkcjonowanie pieniądza elektronicznego nie rozwinęło się dotychczas w większości państw członkowskich". Por. także Commission staff working document on the Review of the E-Money Directive (2000/46/EC), Brussels, 19.07.2006 r., SEC(2006) 1049, http://ec.europa.eu.

25 Por. wniosek KE z dnia 9.10.2008 r., KOM(2008)627 wersja ostateczna 2008/0190 (COD)).

26 Rozporządzenie określa różne okresy dostosowawcze, odmienne dla poszczególnych państw UE, co uzależnione jest od tego, czy walutą państwa jest euro, czy też nie. 
wadzają jednorodnych rozwiązań (państwa członkowskie w wielu przypadkach mogą wyłączyć bądź ograniczyć stosowanie niektórych przepisów ${ }^{27}$. Osiągnięcie jednolitości prawnej może okazać się zatem trudne do zrealizowania. Nie można też pominąć faktu, że transpozycja przepisów dyrektywy PSD napotyka na trudności. Państwa EOG wprowadzają je ze znacznym opóźnieniem ${ }^{28}$. Podobnie jest w przypadku dyrektywy EMD II. W wielu państwach prace legislacyjne nie są $\mathrm{w}$ wystarczającym stopniu zaawansowane, by dotrzymać terminu transpozycji ${ }^{29}$.

\section{JEDNOLITY EUROPEJSKI OBSZAR PŁATNICZY}

Jednolity europejski obszar płatniczy ma być obszarem, w którym zniesione zostaną bariery $\mathrm{w}$ dokonywaniu płatności detalicznych między podmiotami z różnych państw UE. Po implementacji wspólnych zasad i standardów technicznych przez podmioty sektora usług płatniczych, konsumenci, administracja publiczna czy przedsiębiorstwa będą mogli dokonywać ogólnoeuropejskich płatności w sposób tak łatwy, szybki, bezpieczny i tani jak obecnie w swoich krajach.

Projekt SEPA, pomyślany i stworzony przez sektor bankowy, pierwotnie miał być napędzany przez mechanizm rynkowy. Zakładano, że pojawienie się nowych instrumentów i standardów o charakterze paneuropejskim wywoła naturalny proces przechodzenia do tego typu rozwiązań jako lepiej dostosowanych do reguł funkcjonowania jednolitego rynku ${ }^{30}$. Jednakże okazało się, że dla pełnej realizacji projektu SEPA niezbędne jest także wprowadzenie nowych regulacji prawnych.

27 Wskazuje się także na konieczność poprawnej interpretacji przepisów dyrektywy PSD, zob. m.in. E. Van Winkel, The Payment Services Directive: Where are the opportunities for new entrants in the European payments industry?, "Journal of Payments Strategy\&System” 2009, vol. 3, No. 2, s. $105-106$.

28 Termin transpozycji upłynął w dniu 1 listopada 2009 r., tymczasem w czerwcu 2010 r. KE wskazywała, że w sześciu państwach członkowskich UE (na Cyprze, w Grecji, Hiszpanii, Polsce, Rumunii i Szwecji) konieczne jest dopełnienie wdrożenia niektórych bądź nawet wszystkich przepisów dyrektywy PSD, zob. Reference: IP/10/682 Dzień: 03/06/2010; według stanu na październik 2010 w Islandii i Polsce nadal nie przyjęto regulacji dotyczących usług i instytucji płatniczych. Obecnie implementacji nadal nie dokonała Rzeczpospolita Polska, w związku z czym wniesiona została przez Komisję Europejską skarga do Trybunału Sprawiedliwości (Sprawa C-542/10, skarga wniesiona w dniu 17 listopada 2010 r. - Komisja Europejska przeciwko Rzeczypospolitej Polskiej, Dz.U. UE C z 29.01.2011 r., s. 025-025).

29 Termin transpozycji upływa 30 kwietnia $2011 \mathrm{r}$.

30 Projekt SEPA zakłada wprowadzenie jednolitego zestawu instrumentów płatniczych (polecenia przelewu, polecenia zapłaty, płatności kartowe), sprawnej infrastruktury obsługi płatności w euro, wspólnych norm technicznych i praktyk biznesowych oraz jednolitych podstaw prawnych, www.ecb.int, zob. też m.in. K. Lewandowski, Jednolity Obszar Ptatności w Euro (SEPA): koncepcja $i$ wdrożenie, „Prawo Bankowe” 2008, nr 10, s. 90 i n.; D. Rambure, A. Nacamuli, Payment Systems. From the Salt Mines to the Board Room, United Kingdom 2008, s. 77-79. 
W związku $z$ tym, mając na uwadze znaczenie utworzenia jednolitego rynku usług płatniczych, w tworzenie SEPA zaangażowały się także Komisja Europejska i Europejski Bank Centralny ${ }^{31}$.

Dotychczas zasadnicze znaczenie dla zapewnienia ram prawnych SEPA ma przyjęta dyrektywa PSD i dokonane w związku z jej przyjęciem zmiany regulacji dotyczących przelewów transgranicznych oraz instytucji pieniądza elektronicznego. Obecnie przygotowywany jest także kolejny akt prawny mający wpłynąć na zwiększenie integracji rynku płatniczego. Konieczność jego przyjęcia uzasadniana jest faktem, że mimo iż w ramach projektu wprowadzono w dniu 28 stycznia 2008 r. polecenia przelewu SEPA (SCT) oraz w dniu 2 listopada 2009 r. polecenia zapłaty SEPA (SDD), to nadal udział tych instrumentów w rynku nie jest duży, a migracja przebiega wolniej od oczekiwań ${ }^{32}$. Przyczyną takiego stanu rzeczy jest wiele czynników, wśród których można wskazać: niepewność co do ukończenia SEPA oraz wycofania dotychczasowych produktów, konieczność ponoszenia w okresie przejściowym przez dostawców usług płatniczych kosztów związanych $\mathrm{z}$ istniejącymi systemami płatniczymi oraz z nowym systemem SEPA, brak zachęty skłaniającej dostawców usług płatniczych do tworzenia produktów SEPA w pełni zaspokajających potrzeby użytkowników (m.in. brak wystarczającego po-

31 Obecnie zarządzanie SEPA odbywa się na dwóch poziomach. Na poziomie unijnym stworzeniem i rozwojem systemów płatności oraz administracją tymi systemami i nadzorowaniu zgodności z tymi systemami zajmuje się EPC, natomiast KE i EBC wspierają ten proces, wzmacniając jego rangę polityczną i wspierając wdrażanie SEPA (EBC ma status obserwatora na zgromadzeniach plenarnych i grupach roboczych Europejskiej Rady ds. Płatności; zajmuje się także koordynacją prac Eurosystemu; prowadzi różne fora, w tym SEPA High-Level Meeting). Na poziomie krajowym we wszystkich państwach członkowskich należących do strefy euro (a także w prawie wszystkich państwach pozostających poza tą strefą) powołano komitety koordynacyjne ds. SEPA, w których aktywnie uczestniczą narodowe banki centralne, a których celem jest koordynowanie i monitorowanie wdrażania SEPA. Zgodnie z postanowieniami podjętymi przez KE (Komunikat Komisji Wspólnot Europejskich, Dokończenie budowy jednolitego obszaru ptatności w euro (SEPA): plan dziatania na lata 2009-2012, Bruksela, dnia 10.9.2009 r. \{COM/2009/0471\}, http://eur-lex.europa. eu), uwzględniając potrzebę stworzenia nadrzędnego modelu zarządzania SEPA na szczeblu europejskim, usprawniającego integrację rynku płatności detalicznych w euro, powołano także SEPA Council - Radę ds. SEPA [organ ten ma zapewnić zaangażowanie wszystkich zainteresowanych stron w zarządzanie SEPA. Rada kierowana jest przez przedstawicieli KE i EBC, a w jej skład wchodzą: 5 przedstawicieli użytkowników kart (m.in. konsumentów, przedsiębiorstw, władz krajowych), 5 przedstawicieli dostawców (EPC, banków spółdzielczych, kas oszczędnościowych, banków komercyjnych i instytucji płatniczych) oraz 4 przedstawicieli banków centralnych Eurosystemu].

32 Jak wskazano w przygotowanych raportach, na obecnym etapie paneuropejskie instrumenty płatnicze są dalekie od zastąpienia płatności krajowych. Według stanu na kwiecień 2010 r. tylko 7,5\% wszystkich poleceń przelewu przetwarzanych za pomocą mechanizmów rozliczeniowych i rozrachunkowych było realizowanych w formacie SCT, Dokument roboczy stużb Komisji. Streszczenie oceny skutków. Dokument uzupetniający do wniosku w sprawie Rozporzadzenia Parlamentu i Rady ustanawiajacego wymogi techniczne dla poleceń przelewu i poleceń zaptaty w euro oraz zmieniające rozporzqdzenie (WE) nr 924/2009, Bruksela, dnia 16.12.2010 r., SEK(2010) 1583 wersja ostateczna, http://eur-lex.europa.eu. 
pytu na instrumenty SEPA) ${ }^{33}$. Mając na uwadze powyższe, a także fakt, że pełna integracja rynków płatności zostanie osiągnięta dopiero wówczas, gdy ogólnounijne instrumenty płatnicze w pełni zastąpią stosowane dotychczas instrumenty krajowe, KE przygotowała projekt rozporządzenia (rozporządzenie ustanawiające wymogi techniczne dla poleceń przelewu i poleceń zapłaty w euro oraz zmieniające rozporządzenie (WE nr 924/2009) ${ }^{34}$, które ma określić końcowe terminy migracji w odniesieniu do poleceń przelewu w euro i poleceń zapłaty w euro. Istotną kwestią jest także ustanowienie w tym rozporządzeniu określonych, kluczowych norm stosowanych przez sektor usług płatniczych jako obowiązkowe oraz zdefiniowanie wymogów technicznych mających zastosowanie zarówno w odniesieniu do dostawców usług płatniczych, jak i klientów.

Projekt zakłada, że najpóźniej w terminie 12 miesięcy (dla polecenia przelewu) i 24 miesięcy (dla polecenia zapłaty) od daty wejścia w życie tego rozporządzenia polecenia przelewu i polecenia zapłaty denominowane $\mathrm{w}$ euro będą realizowane zgodnie $\mathrm{z}$ określonymi w nim wymogami technicznymi. Jednocześnie założono możliwość, by państwa członkowskie mogły określić terminy wcześniejsze od wyżej wskazanych. Przepisy dotyczyć będą tych transakcji, w których zarówno dostawca usług płatniczych płatnika, jak i dostawca usług płatniczych odbiorcy bądź też jedyny dostawca usług płatniczych w transakcji płatniczej są zlokalizowani na terytorium Unii.

W sposób odmienny dostosowaniu do zasad SEPA podlega paneuropejski rynek kart płatniczych. Kluczowym dokumentem są tzw. Ramy funkcjonowania kart SEPA (ang. SEPA Cards Framework). Mają one charakter generalny, wyznaczając kierunki działań dostosowawczych i ich efekty, do których dążyć mają uczestnicy rynku kartowego. Zawierają szereg wymogów organizacyjno-prawnych dotyczących zasad funkcjonowania systemów kartowych ${ }^{35}$. Równolegle EPC prowadzi program standaryzacji kart płatniczych, a także prace nad ustanowieniem ram przetwarzania transakcji kartowych. Ma to umożliwić usunięcie wszelkich barier dla paneuropejskiej akceptacji ${ }^{36}$.

Rozważając problem wyzwań regulacyjnych dla zintegrowanego rynku płatności, nie można nie wskazać nowych obszarów jego rozwoju. W związku $\mathrm{z}$ postępem $\mathrm{w}$ zakresie nowych technologii obecnie istotnie wzrasta znaczenie

\footnotetext{
33 Por. ibidem.

34 Zob. Wniosek KE z dnia 16.12.2010 r. Rozporzqdzenie Parlamentu Europejskiego i Rady ustanawiajace wymogi techniczne dla poleceń przelewu i poleceń zaptaty weuro, KOM(2010) 775 wersja ostateczna, 2010/0373 (COD), http://eur-lex.europa.eu

35 Ich uzupełnieniem są opublikowane przez Europejski Bank Centralny Terms of Reference for the SEPA compliance of card schemes dostępne na stronie http://www.ecb.int.

36 Zob. Sprawozdanie z wdrażania SEPA w Polsce, ZBP, http://www.sepapolska.pl.
} 
tzw. płatności mobilnych (płatności bezstykowe ${ }^{37}$ i na odległośćc ${ }^{38}$ ). Mając to na uwadze, w grudniu 2010 r. EPC dokonała wstępnej analizy w kwestii przeprowadzania transakcji płatniczych $\mathrm{z}$ wykorzystaniem urządzeń mobilnych (przenośnych) ${ }^{39}$. Wskazano, że najistotniejszymi dla sektora bankowego kategoriami płatności mobilnych, wymieniając w kolejności priorytetu, są: bezstykowe karty SEPA: P2B and B2B; zdalne płatności kartami SEPA: P2P, P2B and B2B; zdalne polecenie przelewu SEPA: P2P, P2B and B2B ${ }^{40}$.

Europejska Rada ds. Płatności podejmuje też działania w celu ustanowienia ram usług w odniesieniu do m-płatności, m.in. w celu ułatwienia płatności SEPA zainicjowanych za pośrednictwem kanału mobilnego. EPC we współpracy z operatorami telefonii komórkowej i innych zainteresowanych stron jest $\mathrm{w}$ trakcie tworzenia niezbędnych standardów i reguł dla dokonywania poleceń przelewu, zapłaty oraz w odniesieniu do płatności kartowych za pośrednictwem telefonów komórkowych.

\section{ZAKOŃCZENIE}

Integracja europejskiego rynku usług płatniczych przebiega wielobiegunowo, a jej celem jest utworzenie jednolitego rynku usług płatniczych. Przyjęcie całego pakietu aktów wyznaczających legalne ramy tego obszaru rynku pozwala na wyznaczenie pożądanych kierunków zmian prawnych na obszarze Unii Europejskiej i z pewnością tworzy warunki dla dalszych. Daje do podstawy do podjętej na łamach artykułu dyskusji o wyzwania regulacyjne, jakie nadal istnieją lub pojawią się w dążeniu do zwiększenia efektywności, konkurencyjności i innowacyjności, ale także bezpieczeństwa rynku płatniczego. Zgodnie z poczynionym na wstępie założeniem płaszczyzną rozważań jest ta odnosząca się do zadań realizowanych w ramach prawa unijnego i krajowego oraz wyznaczenia celów i kierunków zmian prawnych przez organy stanowiące prawo na każdym z poziomów.

$\mathrm{Na}$ poziomie ponadnarodowym o zasadności i granicach ingerencji prawodawczej, z punktu widzenia formalnoprawnego, rozstrzygają ogólne reguły dotyczące stanowienia prawa wyrażone $\mathrm{w}$ traktatach. W aspekcie materialnoprawnym, w omawianym kontekście, zadaniem organów UE jest tworzenie przepisów

\footnotetext{
37 Płatności z wykorzystaniem bezkontaktowych technologii radiowych, jak RFID czy Bluetooth.

38 Płatności, w których transakcja jest przeprowadzana przez sieć telekomunikacyjną, taką jak GSM czy Internet.

39 Zob. White paper Mobile Payments. 1st edition. Document EPC492-09 Version 2.0 Date 18th June 2010, http://www.europeanpaymentscouncil.eu

40 Person-to-Person (P2P), Person-to-Business (P2B), Business-to-Business (B2B).
} 
prawnych organizujących gospodarkę z zachowaniem zasad konkurencji, swobody prowadzenia działalności, ochrony konsumenta, i, co jest istotnie ważne zwłaszcza w obszarze rynku finansowego, bezpieczeństwa. Wyzwaniem, z którym muszą się one mierzyć w pierwszej kolejności, jest odrębność porządków prawnych każdego z państw, dająca w konsekwencji złożony system, który można integrować, ograniczając się do wyznaczania pewnych standardów i dopuszczania stosowania odrębnych uregulowań (opcji narodowych) na rynku usług płatniczych ${ }^{41}$. Dążąc do integracji tego rynku, prawodawca unijny musi uwzględniać także, że państwa członkowskie znajdują się na różnym etapie realizacji unii gospodarczej i walutowej. Konsekwencją tego stanu rzeczy jest stosowanie odmiennych norm prawnych dla krajów, które przeszły do pełnej unii walutowej (strefa euro), oraz tych, które pozostają na wcześniejszym etapie integracji (poza strefą euro) ${ }^{42}$. Państwa, w których przyjęto jednolitą walutę europejską, obligowane są do wcześniejszego wdrażania dalej idących regulacji, podczas gdy pozostałym pozostawia się dłuższe okresy dostosowawcze ${ }^{43}$.

Niezwykle doniosłą kwestią w określaniu prawnych zasad świadczenia usług płatniczych w UE jest wyważenie proporcji między bezpieczeństwem uczestników rynku oraz ochroną konsumenta a umożliwieniem różnym kategoriom dostawców usług płatniczych dostępu do rynku ${ }^{44}$. Normy określające licencjonowanie i nadzorowanie działalności płatniczej nie mogą być zbyt restrykcyjne, zniechęcałyby bowiem do podejmowania i prowadzenia tej działalności.

Prowadząc rozważania nad zadaniami, jakim aktualnie musi sprostać prawodawca europejski, regulując rynek usług płatniczych, nie można pominąc dynamiki rozwoju technologicznego i tworzenia nowych rozwiązań z wykorzystaniem najnowszych osiągnięć techniki. Regulacje prawne muszą być odpowiednio elastyczne, by nie ograniczać rozwoju innowacji w dziedzinie płatności. Dla zapewnienia efektywności i integracji rynku usług płatniczych wskazane byłoby także podejmowanie inicjatyw prawodawczych, zanim wprowadzone zostaną regulacje krajowe. Wyeliminowałoby to niekorzystne zjawiska, przede wszystkim koniecz-

41 Szerzej o problemach z tym związanych: M. van Empel, op. cit., s. 921-940; M.C. Malaguti, The Payment Services Directive: Pitfalls between the Acquis Communautaire and National Implementation, European Credit Research Institute, Research Report No. 9/March 2009, s. 27-30.

42 Szerzej: A. Nowak-Far, Unia gospodarcza i walutowa w Europie, Warszawa 2001, s. 43 i n.

43 Por. np. art. 6 i 7 rozporządzenia Parlamentu Europejskiego i Rady (WE) nr 924/2009 w sprawie płatności transgranicznych we Wspólnocie.

${ }_{44} \mathrm{~W}$ trakcie prac legislacyjnych rozważane były przykładowo różne koncepcje kwalifikacji instytucji płatniczych. EBC stanął na stanowisku, że świadczenie usług płatniczych powinno być, o ile to możliwe, ograniczone do instytucji kredytowych i pieniądza elektronicznego (zobacz pkt 5.1 opinii EBC o usługach płatniczych na rynku wewnętrznym (CON/2006/21), Dz.U. UE C 109 z 9.5.2006, s. 010-030), to wiązałoby się jednak z istotnym ograniczeniem dostępu do rynku niektórych dostawców. 
ność dostosowywania już istniejących narodowych rozwiązań prawnych, ale także technicznych, organizacyjnych, do tych przyjętych na szczeblu europejskim i znacznie ograniczyłoby koszty ich wdrażania. Zważywszy jednak na długość procesu legislacyjnego jest to postulat trudny do zrealizowania przy jednoczesnej ogromnej dynamice rozwoju technologicznego.

Ogólnie ujętym celem działań legislacyjnych powinno być zatem, po pierwsze, dążenie do zapewnienia spójności norm, zasad i procesów we wszystkich państwach EOG dla stworzenia zintegrowanego rynku płatności (wspieranie uproszczenia procesów płatniczych, znormalizowane płatności oraz zapewnienie powszechności ogólnoeuropejskich instrumentów płatniczych, tak by w pełni zastąpiły stosowane dotychczas instrumenty krajowe etc.); po drugie - tworzenie jednolitych możliwości funkcjonowania dla wszystkich podmiotów rynkowych oferujących usługi płatnicze na rynku wewnętrznym z uwzględnieniem zasad bezpieczeństwa, konkurencyjności i ochrony konsumenta; po trzecie - stanowienie norm sprzyjających ogólnounijnemu wdrażaniu innowacji w obszarze płatności.

Drugą płaszczyzną regulacji europejskiego rynku usług płatniczych są przepisy państw członkowskich. Ustanowienie nowych norm na poziomie unijnym wpływa na kształt krajowych porządków prawnych. Pozycję prawa unijnego oraz reguły jego transpozycji określają traktaty oraz orzecznictwo ETS, przyjmując zasadę: pierwszeństwa prawa wspólnotowego wobec prawa krajowego państw członkowskich, skutku bezpośredniego, lojalności, efektywności, a także najwyższego standardu ${ }^{45}$. Mając na względzie, że prawo unijne $z$ założenia jest autonomiczne i nie odzwierciedla kultury prawnej żadnego państwa członkowskiego, co wpływa m.in. na język prawa europejskiego (jego zakładaną „neutralność) czy sposób wykładni pojęć i instytucji, wyzwaniem legislacyjnym jest w pierwszej kolejności prawidłowe odtworzenie z przepisów europejskich norm prawnych niezbędnych dla implementacji, a także stosowania i egzekwowania prawa w sposób jednolity w całej $\mathrm{UE}^{46}$. Następnie jest nim prawidłowe wkomponowanie regu-

45 Szerzej: J. Barcz, Prawo wspólnotowe a prawo krajowe państw cztonkowskich, [w:]: J. Barcz, E. Kawecka-Wyrzykowska, K. Michałowska-Gorywoda, Integracja europejska, Warszawa 2007, s. 115-117; K. Kemppainen, Competition and regulation in European retail payment systems, Bank of Finland, Discussion Papers 2003, No. 16, s. 14-16.

${ }_{46} \mathrm{~W}$ praktyce neutralne terminy tworzone i stosowane na poziomie Unii Europejskiej są często przekładane na język i terminologię prawa krajowego (por. J.M. Smits, The Europeanisation of national legal systems: some consequences for legal thinking in civil law countries, [w:] Epistemology and Methodology of Comparative Law, red. M. Van Hoecke, Oxford 2004, s. 235), co nie zawsze prowadzi do uchwycenia właściwego, ustalonego w regulacjach wspólnotowych znaczenia (por. E. Fojcik-Mastalska, Nowe definicje legalne w prawie rynku finansowego, Gdańskie Studia Prawnicze 2007, t. XVI, s. 543-544). Także sam proces wykładni przepisów UE różni się od wykładni prawa krajowego, co jest wynikiem ponadnarodowego charakteru wspólnotowego systemu prawnego oraz „wielojęzyczności” prawa w UE. 
lacji unijnych w system prawa krajowego ${ }^{47}$. Obecnie trudno jeszcze rozstrzygać o stopniu ewentualnych rozbieżności wynikających z niepełnego czy niepoprawnego włączenia norm wspólnotowych do porządków prawnych poszczególnych państw EOG w odniesieniu do dyrektyw regulujących segment usług płatniczych. Nie został bowiem zakończony proces transpozycji przepisów dyrektywy PSD, a także dyrektywy EMD II. Ocena ich rzeczywistego wpływu na postęp integracji rynku płatniczego także nie jest $\mathrm{w}$ związku $\mathrm{z}$ tym $\mathrm{w}$ pełni możliwa. Niewątpliwie wprowadzone zharmonizowane ramy ich świadczenia przyczynią się do utworzenia ogólnowspólnotowego wewnętrznego rynku usług płatniczych, choć z założenia wprowadzona została możliwość przyjęcia odmiennych regulacji w niektórych obszarach (opcje narodowe). Różnice w zakresie warunków świadczenia usług płatniczych, przysługujących stronom uprawnień, nakładanych na nie obowiązków w przypadku płatności dokonywanych w poszczególnych państwach unii, a także instrumentów płatniczych, co wynika z prawnych i historycznych uwarunkowań ${ }^{48}$, będą zatem nadal obecne w każdym z porządków prawnych. Zadaniem prawodawcy krajowego jest rozstrzygnięcie, jak dalece możliwa jest harmonizacja (w obszarze nieobjętym przymusem wprowadzenia wspólnych, jednolitych regulacji), a na ile konieczne jest utrzymanie rozwiązań odmiennych, tak by w rezultacie umożliwić utworzenia ogólnowspólnotowego wewnętrznego rynku usług płatniczych, modernizację płatności oraz tworzenie nowych usług na płaszczyźnie paneuropejskiej, takich jak płatności mobilne i internetowe czy e-fakturowanie.

Dotychczasowe doświadczenia nie pozostawiają wątpliwości, że dla pełnej realizacji celów gospodarczych, jakie wyznaczają sobie państwa EOG, w wielu przypadkach konieczne jest tworzenie przepisów prawnych organizujących gospodarkę na poziomie wyższym niż porządek krajowy, co coraz wyraźniej widać także w odniesieniu do regulacji rynku płatniczego. Jednak dynamika rozwoju technologicznego i pojawiające się innowacje techniczne często wymuszają na prawodawcach krajowych podejmowanie działan legislacyjnych przed legislatorem unijnym. Organy stanowiące prawo na szczeblu narodowym powinny także wówczas uwzględniać cel, jakim jest otwarty, przejrzysty, zintegrowany rynek płatności pomimo braku jednolitych ogólnoeuropejskich standardów.

Istotnym obszarem aktywności prawodawczej jest też sfera bezpieczeństwa rynku płatniczego. W tym kontekście szczególne znaczenie ma przeciwdziałanie zagrożeniom destabilizacji rynku finansowego i podejmowanie działań słu-

${ }^{47}$ W przypadku dyrektyw prawidłowa transpozycja, natomiast w odniesieniu do rozporządzeń podjęcie działań legislacyjnych zarówno wykonawczych, jak i uzupełniających (por. C. Mik, Wyktadnia zgodna z prawem Unii Europejskiej, [w:] Polska kultura prawna a proces integracji europejskiej, red. S. Wronkowska, Kraków 2005, s. 140).

48 SEPA Migration end-date. Discussion Paper, op. cit., s. 4. 
żących zapewnieniu tzw. stabilności finansowej (bezpieczeństwo ekonomiczne) ${ }^{49}$. Doniosłą funkcję pełnią tu organy nadzoru, których cele, zadania i kompetencje nadzorcze wyznaczone przepisami prawa powinny umożliwiać sprawowanie efektywnego nadzoru ${ }^{50}$. Należy też wskazać, że postępujący rozwój oraz integracja rynku usług płatniczych rodzą również zagrożenia w postaci różnego rodzaju przestępstw (m.in. prania pieniędzy czy nadużyć i fałszerstw związanych $z$ bezgotówkowymi środkami płatniczymi). W związku z tym zarówno na szczeblu krajowym, jak i unijnym wprowadzane muszą być regulacje, których celem jest szeroko pojęta prawnokarna ochrona bezpieczeństwa obrotu płatniczego ${ }^{51}$.

\section{BIBLIOGRAFIA}

Bacia B., Zawidzka A., Swoboda przeptywu kapitatu i ustugi finansowe w Unii Europejskiej, Warszawa 2011.

Barcz J., Prawo wspólnotowe a prawo krajowe państw cztonkowskich, [w:] J. Barcz, E. Kawecka-Wyrzykowska, K. Michałowska-Gorywoda, Integracja europejska, Warszawa 2007.

Braun T., Lipowski T., Ocena projektu dyrektywy w sprawie ptatności na Rynku Werwnętrznym Unii Europejskiej, „Przegląd Prawa Handlowego” 2005, nr 10.

Byrski J., Outsourcing wdziatalności dostawców ustug ptatniczych na tle dyrektywy w sprawie ustug ptatniczych w ramach rynku wewnętrznego, „Przegląd Prawa Handlowego” 2009, nr 9.

Empel M. van, Retail payments and the arduous road to SEPA, „Common Market Law Review" 2009, vol. 46, No. 3.

Fojcik-Mastalska E., Nowe definicje legalne w prawie rynku finansowego, Gdańskie Studia Prawnicze 2007, t. XVI.

Fojcik-Mastalska E., Ewolucja ustawodawstwa poświęconego przeciwdziataniu praniu pieniędzy i finansowaniu terroryzmu, [w:] System finansów publicznych. Prawo finansowe

49 Szerzej: A. Jurkowska-Zeidler, Bezpieczeństwo rynku finansowego w świetle prawa Unii Europejskiej, Warszawa 2008, s. 166-171; T. Nieborak, Aspekty prawne funkcjonowania rynku finansowego Unii Europejskiej, Warszawa 2008.

50 Dążąc do jego zapewnienia na poziomie krajowym, państwa członkowskie obecnie konkurują nie w zakresie standardów regulacyjnych, te bowiem określane są w sposób jednolity w całej UE, a efektywnością i wydajnością nadzoru. Z drugiej strony ostatni kryzys finansowy wymusił także na prawodawcy unijnym zmianę koncepcji i organizacji nadzoru, czego wyrazem jest funkcjonująca od dnia 1 stycznia 2011 r. nowa ,architektura” nadzoru na unijnym rynku finansowym.

51 Szerzej m.in.: E. Fojcik-Mastalska, Ewolucja ustawodawstwa poświęconego przeciwdziataniu praniu pieniędzy ifinansowaniu terroryzmu, [w:] System finansórw publicznych. Prawo finansowe wobec wyzwań XXI wieku, red. A. Dobaczewska, E. Juchniewicz, T. Sowiński, Warszawa 2010, s. 226-227; A. Grzelak, Prawnokarna ochrona obrotu gospodarczego jako element konstytucji gospodarczej Unii Europejskiej, [w:] Konstytucja gospodarcza Unii Europejskiej. Aksjologia, red. A. Nowak-Far, Warszawa 2010, s. 180-186. 
wobec wyzwań XXI wieku, red. A. Dobaczewska, E. Juchniewicz, T. Sowiński, Warszawa 2010.

Gliniecka J., Zasada przejrzystości świadczenia ustug ptatniczych jako warunek bezpiecznego korzystania z elektronicznych instrumentów ptatniczych na tle rozwiazań prawnych $d y$ rektywy PSD, „Prawo Bankowe” 2008, nr 6.

Grzelak A., Prawnokarna ochrona obrotu gospodarczego jako element konstytucji gospodarczej Unii Europejskiej, [w:] Konstytucja gospodarcza Unii Europejskiej. Aksjologia, red. A. Nowak-Far, Warszawa 2010.

Jurkowska-Zeidler A., Bezpieczeństwo rynku finansowego w świetle prawa Unii Europejskiej, Warszawa 2008.

Kaszubski R., Widawski P., Nowy porzadek prawny dla ustug ptatniczych na Rynku Wewnętrznym UE, „Glosa” 2004, nr 9.

Kemppainen K., Competition and regulation in European retail payment systems, Bank of Finland, Discussion Papers 2003, No. 16.

Lannoo K., EU Retail Financial Market Integration: Mirage or Reality?, European Credit Research Institute Policy, Brief 2008, No. 3, s. 1-2.

Lewandowski K., Jednolity Obszar Ptatności w Euro (SEPA): koncepcja i wdrożenie, „Prawo Bankowe” 2008, nr 10, s. 90.

Malaguti M.C., The Payment Services Directive: Pitfalls between the Acquis Communautaire and National Implementation, European Credit Research Institute, Research Report No. 9/March 2009.

Mavromati D., The Law of Payment Services in the EU. The EC Directive on Payments Services in the Internal Market, Kluwer Law International, The Netherlands 2008.

Mik C., Wyktadnia zgodna z prawem Unii Europejskiej, [w:] Polska kultura prawna a proces integracji europejskiej, red. S. Wronkowska, Kraków 2005.

Nieborak T., Aspekty prawne funkcjonowania rynku finansowego Unii Europejskiej, Warszawa 2008.

Nowak-Far A., Unia gospodarcza i walutowa w Europie, Warszawa 2001.

Rambure D., Nacamuli A., Payment Systems. From the Salt Mines to the Board Room, United Kingdom 2008.

Smits J.M., The Europeanisation of national legal systems: some consequences for legal thinking in civil law countries, [w:] Epistemology and Methodology of Comparative Law, red. M. Van Hoecke, Oxford 2004.

Usher J.A., The Law of Money and Financial Services in the EC, Oxford 2000.

Winkel E. van, The Payment Services Directive: Where are the opportunities for new entrants in the European payments industry?, „Journal of Payments Strategy \& System” 2009, vol. 3 , No. 2.

\section{AKTY PRAWNE}

Traktat o Unii Europejskiej i Traktat o funkcjonowaniu Unii Europejskiej, wersje skonsolidowane Dz.U. UE C 83 z 30.3.2010, s. 001-388.

Dyrektywa 95/5/WE Parlamentu Europejskiego i Rady z 27 stycznia 1997 r. w sprawie transgranicznych przelewów bankowych; Dz.U. UE L 043 z 14.02.1997, s. 025-030. 
Dyrektywa 2000/46/WE Parlamentu Europejskiego i Rady z dnia 18 września 2000 r. w sprawie podejmowania i prowadzenia działalności przez instytucje pieniądza elektronicznego oraz nadzoru ostrożnościowego nad ich działalnością, Dz.U.UE L 275 z 27.10.2000, s. 039-043.

Dyrektywa 2006/48/WE Parlamentu Europejskiego i Rady z dnia 14 czerwca 2006 r. w sprawie podejmowania i prowadzenia działalności przez instytucje kredytowe, Dz.U. UE L 177 z 30.06.2006, s. 001-003.

Dyrektywa Parlamentu Europejskiego i Rady 2007/64/WE z dnia 13 listopada 2007 r. wsprawieusługpłatniczychwramachrynkuwewnętrznegozmieniającadyrektywy 97/7/ WE, 2002/65/WE, 2005/60/WE i 2006/48/WE i uchylająca dyrektywę 97/5/WE, Dz.U. UE L 319 z 5.12.2007, s. 001-036.

Dyrektywa Parlamentu Europejskiego i Rady 2009/110/WE z dnia 16 września 2009 r. w sprawie podejmowania i prowadzenia działalności przez instytucje pieniądza elektronicznego oraz nadzoru nad działalnością, zmieniająca dyrektywy 2005/60/WE i 2006/48/WE oraz uchylająca dyrektywę 2000/46/WE,Dz.U.UE L 267 10.10.2009, s. 007-017.

Rozporządzenie (WE) nr 2560/2001 Parlamentu Europejskiego i Rady z dnia 19 grudnia 2001 r. w sprawie płatności transgranicznych w euro, Dz.U. UE L 344 z 28.12.2001, s. 013-016.

Rozporządzenie (WE) nr 1781/2006 Parlamentu Europejskiego i Rady z dnia 15 listopada 2006 r. w sprawie informacji o zleceniodawcach, które towarzyszą przekazom pieniężnym, Dz.U. UE L 345 z 8.12.2006, s. 001-009.

Rozporządzenie Parlamentu Europejskiego i Rady (WE) nr 924/2009 z 16 września 2009 r. w sprawie płatności transgranicznych we Wspólnocie oraz uchylające rozporządzenie (WE) nr 2560/2001, Dz.U. UE L 266 z 9.10.2009, s. 011-018.

Rozporządzenie Parlamentu Europejskiego i Rady Nr 1093/2010 z dnia 24 listopada 2010 r. w sprawie ustanowienia Europejskiego Urzędu Nadzoru (Europejskiego Urzędu Nadzoru Bankowego), zmiany decyzji nr 716/2009/WE oraz uchylenia decyzji Komisji 2009/78/WE, Dz.U. UE L 331 z 15.12.2010, s. 012-047.

Zalecenie Komisji 87/598/EEC z 8 grudnia 1987 r. w sprawie europejskiego kodeksu właściwego zachowania w zakresie elektronicznych instrumentów płatniczych (dotyczące relacji między instytucjami finansowymi, akceptantami i agentami rozliczeniowymi i konsumentami), Dz.U. UE L 365 z 24.12.1987, s. 072-076.

Zalecenie 88/590 Komisji z 17 listopada 1988 r. dotyczące systemów płatności, w szczególności stosunków pomiędzy posiadaczem karty i wydawcą karty, Dz.U. UE L 317 z 24.11.1988, s. 055-058.

Zalecenie Komisji 90/109/EWG z dnia 14 lutego 1990 r. w sprawie przejrzystości warunków bankowych związanych z zagranicznymi transakcjami finansowymi, Dz.U. UE L 67 z 15.03.1990, s. 039-043.

Zalecenie Komisji nr 97/489/EC z 30 lipca 1997 r. w sprawie transakcji dokonywanych przy użyciu elektronicznych instrumentów płatniczych, w szczególności stosunków pomiędzy wydawcą a posiadaczem, Dz.U. UE L 208 z 02.08.1997, s. 052-058. 


\section{POZOSTAŁE ŹRÓDŁA}

Biata Ksiega. Polityka w dziedzinie ustug finansowych na lata 2005-2010 \{SEC(2005) 1574\}, Komisja Wspólnot Europejskich, Bruksela, dnia 1.12.2005 COM (2005) 629 final, http://ec.europa.eu/internal_market/finances/docs/white_paper/white_paper_pl.pdf.

Commission staff working document - Initiatives in the area of Retail Financial Services Accompanying document to the Communication from the Commission to the European Parliament, the Council, the European Economic and Social Committee and the Committee of the Regions - A single market for 21st century Europe $\{C O M(2007) 724$ final\} $\{S E C(2007) 1517\}\{S E C(2007) 1518\}\{S E C(2007) 1519\}\{S E C(2007) 1521\}$, http:// eur-lex.europa.eu/.

Commission staff working document on the Review of the E-Money Directive (2000/46/EC), Brussels, 19.07.2006, SEC(2006) 1049, http://ec.europa.eu/internal_market/bank/ docs/e-money/working-document_en.pdf.

Dokument roboczy stużb Komisji. Streszczenie oceny skutków. Dokument uzupetniający do wniosku w sprawie Rozporzadzenia Parlamentu i Rady ustanawiajacego wymogi techniczne dla poleceń przelewu i poleceń zaptaty w euro oraz zmieniajace rozporzqdzenie (WE) nr 924/2009, Bruksela, dnia 16.12.2010, SEK(2010) 1583 wersja ostateczna, http:// eur-lex.europa.eu/LexUriServ/LexUriServ.do?uri=SEC:2010:1583:FIN:PL:PDF.

Komunikat Komisji dla Parlamentu Europejskiego, Rady, Europejskiego Komitetu Ekonomiczno-Spotecznego i Komitetu Regionów - Jednolity rynek Europy XXI wieku \{KOM(2007) 725 wersja ostateczna\} \{SEK(2007) 1517\} \{SEK(2007) 1518\} \{SEK(2007) 1519\} $\{S E K(2007) 1520\}\{S E K(2007) 1521\} / C O M / 2007 / 0724$ końcowy, Bruksela, dnia 20.11.2007, http://eur-lex.europa.eu/.

Komunikat Komisji Wspólnot Europejskich, Dokończenie budowy jednolitego obszaru ptatności w euro (SEPA): plan dziatania na lata 2009-2012, Bruksela, dnia 10.9.2009 \{COM/2009/0471\}), http://eur-lex.europa.eu/LexUriServ/LexUriServ.do?uri=COM:2009:0471:FIN:PL:PDF.

Opinia EBC o ustugach ptatniczych na rynku wewnętrznym (CON/2006/21), Dz.U.Urz.C 109 z 9.5.2006.

SEPA Migration end-date. Discussion Paper, PSMEG/002/10, 15.03.2010, http://www. europeanpaymentscouncil.eu/knowledge_bank_download.cfm?file=PSMEG00210 EC Discussion Paper End Date.pdf.

Single Euro Payments Area. Sixth Progress report, www.ecb.int/pub/pdf/other/singleeuropaymentsarea200811en.pdf.

Sprawozdanie z wdrażania SEPA w Polsce, ZBP, http://www.sepapolska.pl/files/za322;3_ Sprawozdanie_SEPA_2010_v1.0.pdf.

Terms of Refrence for the SEPA compliance of card schemes, dostępne na stronie http://www. ecb.int.

White paper Mobile Payments. 1st edition. Document EPC492-09 Version 2.0 Date 18th June 2010, http://www.europeanpaymentscouncil.eu.

Wniosek KE z dnia 16.12.2010 r. Rozporzqdzenie Parlamentu Europejskiego i Rady ustanawiajace wymogi techniczne dla poleceń przelewu i poleceń zaptaty w euro, KOM(2010) 
775 wersja ostateczna, 2010/0373 (COD), http://eur-lex.europa.eu/LexUriServ/LexUriServ.do?uri=COM:2010:0775:FIN:PL:HTML.

Wniosek KE z dnia 9.10.2008 r. Dyrektywa Parlamentu Europejskiego i Rady w sprawie podejmowania i prowadzenia dziatalności przez instytucje pieniadza elektronicznego oraz nadzoru ostrożnościowego nad ich dziatalnościq, zmieniajaca dyrektywy 2005/60/WE i 2006/48/WE oraz uchylająca dyrektywę 2000/46/WE (Tekst majacy znaczenie dla EOG) $\{\mathrm{SEK}(2008) 2572\}\{\operatorname{SEK}(2008) 2573\} / \mathrm{KOM} / 2008 / 0627$ wersja ostateczna - COD 2008/0190; http://eur-lex.europa.eu/LexUriServ/LexUriServ.do?uri=COM:2008:0627:FIN:PL:HTML.

Wspólne oświadczenie Europejskiego Banku Centralnego i Komisji Europejskiej dotyczace przyjęcia przez Parlament Europejski dyrektywy w sprawie ustug ptatniczych, Reference: IP/07/550, dzień: 24/04/2007, http://europa.eu/rapid/pressReleasesAction.do?reference $=\mathrm{IP} / 07 / 550 \&$ format $=$ HTML\&aged $=1$ \&language $=$ PL\&guiLanguage $=$ fr .

\section{EUROPEAN PAYMENTS MARKET INTEGRATION PROCESS - REGULATION CHALLENGES}

SUMMARY

The European payments market has recently been subjected to intense transformation. This results from the fact that the economic integration process in the making (with monetary integration being a part of this) makes possible, or even forces, the implementation of new instruments or legal solutions which increase the effectiveness of economic processes; among others, through the realisation of the free flow of capital and payments between countries.

Some of the new legal acts of the European Union and the SEPA initiative were launched in order to enable and facilitate the integration of the European payments market. Thus, it is important to consider whether they will have a major influence on payment services in the internal market. On the other hand, a no less important question is that of the regulatory changes which lie before European and domestic legislators in order to achieve the integration of the payment market.

The legal framework for payment services in the internal market of the EU and the European Economic Area (EEA) was described in the first part of the article. Directive 2007/64/EC on payment services in the internal market (PSD), adopted by the European Parliament and the Council of the European Union, comes under particular analysis. The building of the Single Euro Payments Area (SEPA) is the second important part of this research. Although SEPA is a self-regulatory initiative of the banking sector, the legislative initiative at the level of the European Commission was undertaken to support a fully integrated and highly standardised payments market. Both the European Payments Council's and European Commission's actions have been analysed.

Finally, the problems of national and European legislators have been formulated based on analysis. 